Jurnal At-Tibyan: Jurnal Ilmu Alqur'an dan Tafsir

Volume 6 No. 2, Desember 2021 (p. 361-377)

P ISSN 2442-594X | E ISSN 2579-5708

http://journal.iainlangsa.ac.id/index.php/tibyan

\title{
THE CRIMINALIZATION OF THE QUR'AN PERSPECTIVE AND IT'S CONTEXTUALIZATION IN INDONESIA
}

\author{
Nawawi Marhaban \\ Insitut Agama Islam Negeri Langsa, Indonesia \\ nawawi@iainlangsa.ac.id \\ \begin{tabular}{|l|l|l|}
\hline \multicolumn{2}{|c|}{ DOI 10.32505/at-tibyan.v6i2.3418 } \\
\hline Submitted: 27-10-2021 & Revised: 18-12-2021 & Accepted: 22-12-2021 \\
\hline
\end{tabular}
}

\begin{abstract}
The Qur'an as the main source of law in Islam rules various kinds of criminal offenses and their punishments called Jañmah. This is relevant to the purpose of God's laws implemented for the benefit and happiness of human beings. This article aims to present the discourse of Islamic criminal law in the Indonesian context. By using library research and content analysis as the analytical knife, this study found that the punishment in terms of the existence of texts in the Qur'an and hadith consists of two kinds. First, the punishments directly mentioned in the text are $h u d \bar{u} d$, qișas, diyāt and kafarāt. Second, the punishment uncovered by the text is the ta'zir punishment. Furthermore, there are four kinds of relations in the punishment, namely; 1) principal punishment, 2) substitute punishment, 3) additional punishment, and 4) complementary punishment. In this study, there are also ten acts that are able to be criminalized with threats of hadd and qis as punishment, namely zinā, qażāf (accusing zinā without evidence), hirābah (robbery), sañqah (theft), syurb al-khāmr (drinking wine), maisìr (gambling), riddāh (apostasy), murder, persecution, and al-bugyu (rebellion).
\end{abstract}

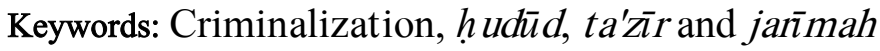

\begin{abstract}
Abstrak
Al-Qur'an sebagai sumber hukum utama dalam Islam, telah mengatur berbagai macam pelanggaran kepidanaan beserta sanksi hukumannya yang disebut Jañmah. Hal ini relevan dengan tujuan disyariatkan hukum-hukum Allah di muka bumi ini untuk kemaslahatan dan kebahagiaan manusia itu sendiri. Tujuan artikel ini untuk menghidupkan pidana Islam dalam kancah pidana di Indonesia. Dengan menggunakan penelitian pustaka dan analisis isi (content analisis) sebagai pisau analisnya. Penelitian ini menemukan bahwa pemidanaan dilihat dari segi ada atau tidaknya nash dalam al-Quran dan hadis
\end{abstract}


terdapat dua macam yaitu; Pertama, hukuman yang ada nash-nya yaitu h̆udūd, qișaș, diyāt dan kafarāt. Kedua, hukuman yang tidak ada nashnya yaitu hukuman ta'zir. Sementara relasi antar pemidanaan terdapat empat macam relasi, yaitu; 1) pidana pokok, 2) pidana pengganti, 3) pidana tambahan, dan 4) pidana pelengkap. Dalam penelitian ini juga terdapat sepuluh perbuatan yang dapat dipidanakan dengan ancaman dikenakan sanksi hadd dan qiṣas yaitu zinā, qażf (menuduh zin̄̄ tanpa bukti), hirābah (perampokan), sañqah (pencurian), syurb al-khāmr (minum khamar), maisīr (judi), riddāh (murtad), pembunuhan, penganiayaan, dan al-bugyu (pemberontakan).

Kata kunci: Pemidanaan, hudùd, ta'zìr dan jarimah.

\section{Introduction}

The Qur'an is a source of Islamic law that occupies a central position in Islamic studies. Besides functioning as a guide, it becomes a benchmark and a differentiator between truth and falsehood, including accepting and rejecting any news based on the prophet Muhammad SAW. The legal content of the Qur'an includes the law of worship, family law, inheritance, the law on the property (wealth), exchange, and criminal law ('uqubāt or jinayāt) relating to civil matters. ${ }^{1}$ Islamic criminal law is God's law which contains benefits for human life both in the world and the hereafter. The concept of sharia human rights obligations, namely placing God as the holder of all rights, both those that exist in oneself and those of others. ${ }^{2}$ Everyone is only an executor who is obliged to fulfill Allah's commands. God's command is meant, must be fulfilled for the benefit of himself and others. ${ }^{3}$

In general criminal law theory, seven terms refer to criminal acts, namely criminal acts, criminal events, offenses, criminal offenses, punishable acts, punishable acts, and criminal acts. ${ }^{4}$ A criminal act is a charge that is prohibited by a rule of law, the prohibition of which is accompanied by threats (sanctions) in the form of certain crimes, for anyone who violates the prohibition. At the same time, it is remembered that the prohibition is aimed at an act (the situation or event caused by the behavior of a person), while the criminal threat is directed at the person who caused the incident. ${ }^{5}$ Meanwhile, in Islamic law, criminal acts are called jañmah, namely crimes, whether committed by a person or by a group of people, intentionally or unintentionally. ${ }^{6}$ The discussion of Islamic criminal acts is included in fiqh jināyah, namely all legal

\footnotetext{
${ }^{1}$ H.A. Wardi Muslich, “Ayat-Ayat Pidana Dalam Al-Qur'an,” Al-Qalam: Jurnal Kajian Keislaman 18, no. 90-91 (2001): 46-73.

${ }^{2}$ Hajed A. Alotaibi, "The Challenges of Execution of Islamic Criminal Law in Developing Muslim Countries: An Analysis Based on Islamic Principles and Existing Legal System," Cogent Social Sciences 7, no. 1 (2021): 1-13, https://doi.org/10.1080/23311886.2021.1925413.

${ }^{3}$ Husnawadi, "Konsep Hukum Pidana Dalam Al-Qur'an," Al Aqidah: Jurnal Studi Islam 1, no. 1 (2018): 1-19.

${ }^{4}$ Adami Chazawi, Pelajaran Hukum Pidana Bagian I(Jakarta: Raja Grafindo Persada, 2012), 5.

${ }^{5}$ Moeljatno, Asas-Asas Hukum Pidana (Jakarta: Reneka Cipta, 1993), 54.

${ }^{6}$ Ali Zainuddin, Hukum Pidana Islam (Jakarta: Sinar Grafika, 2007), 12.
} 
provisions regarding criminal acts or criminal acts committed by mukallāf (legal subjects) as a result of understanding the detailed legal arguments from the Qur'an and hadis. Criminal acts that disturb public peace and acts against laws and regulations that are sourced from the Qur'an and Hadis. ${ }^{7}$

Crimes (jarīmah/jināyat) are defined as legal prohibitions given by Allah, the prohibitions of which bring His prescribed punishment (criminalization). Legal prohibition means doing a prohibited act or not doing an act that is not ordered. Thus, a crime is an act that the Shari'a only prohibits. In other words, doing or not doing an act that leads to the punishment determined by the Shari'a is a crime ${ }^{8}$. Acts that are declared as crimes are active or passive actions that can damage (disturb) the realization of social order, beliefs, individual life, property rights, honor, and acceptable ideas ${ }^{9}$.

Islamic law stipulates specific actions as crimes and threatens them with specific punishments to protect collective interests and the system on which the grand building of society stands. The crime or disobedience of a person or the entire human race does not pose any danger to humans, the environment, and the universe. Allah SWT has laid down the provisions of the Shari'a for humans to live with them. So the definition of criminal acts or jarīmah, as stated above, is prohibited by syara ${ }^{\prime}$, which are threatened with punishment in the form of punishment had or ta'zir. ${ }^{10}$ In general, criminal acts that are seen in terms of legal sanctions are divided into two, namely, the major crime and additional punishment. The main punishment is divided into four types of punishment $^{11}$ namely; First, acts punishable by the death penalty include acts of treason with the intent to kill, seize independence, or negate the ability of the and vice president. Establishing relations with foreign countries to induce them to commit acts of hostility or war against the state, strengthening their intentions, promising assistance or helping prepare them to commit acts of hostility or war against the state, and as a result of which acts of hostility are carried out, or war occurs. Deliberately and premeditated taking the lives of others. Theft preceded, accompanied, or followed by violence against people. Second, criminal acts are punishable by imprisonment. Third, acts are punishable by imprisonment, and Fourth criminal acts are punishable by a fine.

Whereas in Muslich, ${ }^{12}$ Islamic criminal acts or jañmah can be broadly divided based on several aspects, namely: First, in terms of the severity of the punishment is

${ }^{7}$ Zainuddin, Pengantar Hukum Pidana Islam (Yogyakarta: Deepublish, 2019), 27-28.

${ }^{8}$ Topo Santoso, Membumikan Hukum Pidana Islam (Jakarta: Gema Insani Press, 2003), 21.

${ }^{9}$ Santoso, 21.

${ }^{10}$ Andrew Fallon, "Restoration as the Spirit of Islamic Justice," Contemporary Justice Review: Issues in Criminal, Social, and Restorative Justice 23, no. 4 (2019): 1-14, https://doi.org/10.1080/ 10282580.2019.1700370.

${ }^{11}$ Frans Maramis, Hukum Pidana Umum Dan Tertulis Di Indonesia (Jakarta: Raja Grafindo Persada, 2016), 11.

${ }^{12}$ Ahmad Wardi Muslich, Pengantar Dan Asas Hukum Pidana Islam (Fikih Jinayah) (Jakarta: Sinar Grafika, 2006), 16. 
divided into three parts, namely jarimah hudud, jarimah qisas and blood money, and jarimah ta'zīr. Second, in terms of intention, it can be divided into two parts, namely intentional and unintentional. Third, in terms of the timing of the arrests, they were divided into two parts, namely those who were caught red-handed (جر ائم المتلبس بها) and those who were not caught red-handed (جرائم لاتلبس ا). Fourth, in terms of how to do it, it can be divided into two parts, namely positive criminal acts (jañmah), namely actions that occur because of committing prohibited acts, such as theft, adultery, and beatings. And negative criminal acts (jañmah), namely jarimah that happens because of leaving the ordered actions such as not wanting to be a witness, refusing to pray, and fasting. Fifth, in terms of the object or target affected by the finger, it can be divided into two, namely, individual finger (law applies to protect individual rights such as murder) and community finger, which aims to preserve community rights such as theft and qadzaf. Sixth, in terms of character, it can be divided into two, namely, Ordinary Jarimah or someone's actions that are carried out without linking to political goals and both political jarimahs, which are a violation of government regulations or government officials or against political lines that the government has determined.

Researchers have had many discussions about Islamic criminal law, both in the form of books and articles. Several names have discussed Islamic criminal law in the form of books, for example, Masaid who wrote about Al-Fiqh Jinayah (Islamic Criminal Law), ${ }^{13}$ Zainuddin who wrote about an introduction to Islamic criminal law, ${ }^{14}$ Muhammad Nur, an introduction to the principles of Islamic criminal law, ${ }^{15}$ and Sahid who wrote on the epistemology of Islamic criminal law ${ }^{16}$. While some articles also discuss Islamic criminal law, for example, Wardi Muslich, who discusses the criminal verses in the Qur'an, ${ }^{17}$ Sunarto, who discusses Islamic criminal law and its sanctions in the perspective of the Qur'an, ${ }^{18}$ Ahmad Syafiq, who discusses the reconstruction of punishment in Islamic criminal law in the perspective of legal philosophy, ${ }^{19}$ and Reni Surya discusses the classification of hudud crimes and their sanctions in the perspective of Islamic law. ${ }^{20}$

By using this type of literature research sourced from books, and scientific articles on Islamic crime and using Content Analysis, this article would like to show that the current policy of formulating the criminal system in positive law is still largely

\footnotetext{
${ }^{13}$ Marsaid, Al-Fiqh Al-Jinayah ( Hukum Pidana Islam ) (Palembang: Rafah Press, 2020).

${ }^{14}$ Zainuddin, Pengantar Hukum Pidana Islam.

${ }^{15}$ Muhammad Nur, Pengantar Dan Asas-Asas Hukum Pidana Islam (Banda Aceh: Yayasan PeNA Aceh, 2020).

${ }^{16}$ Sahid, Epistemologi Hukum Pidana Islam (Dasar-Dasar Pidana Islam) (Surabaya: Pustaka Idea, 2015).

${ }^{17}$ Muslich, “Ayat-Ayat Pidana Dalam Al-Qur'an."

${ }^{18}$ Sunarto, "Konsep Hukum Pidana Islam Dan Sanksinya Dalam Perspektif Al-Qur'an," Kordinat: Jurnal Komunikasi Antar Perguruan Tinggi Agama Islam XIX, no. 1 (2020): 97-112.

${ }^{19}$ Ahmad Syafiq, "Rekonstruksi Pemidanaan Dalam Hukum Pidana Islam (Perspektif Filsafat Hukum)," Jurnal Pembaharuan Islam 1, no. 2 (2014): 178-90.

${ }^{20}$ Reni Surya, "Klasifikasi Tindak Pidana Hudud Dan Sanksinya Dalam Perspektif Hukum Islam," Samarah: Jurnal Hukum Keluarga Dan Hukum Islam 2, no. 2 (2018): 530-47.
} 
oriented towards criminals. In contrast, a small portion of it is still oriented towards criminals. / a total of 21 (twenty one) victim-oriented. In this article, we will discuss the concept of punishment according to the Qur'an by reviewing some literature in the form of books and other scientific articles. The discussion of this article follows the flow of tracing several criminal acts or jañmah hudūd that can criminalize the perpetrators.

\section{The Concept of Islamic Criminal Law}

The term punishment in Arabic is often called 'uqübah, which is a form of retaliation for someone for his actions that violate the provisions of syara' set by Allah SWT and His Messenger. ${ }^{21}$ Another definition states that punishment is suffering imposed on a person due to his actions violating the rules. Criminalization with specific penalties are intended to bring the benefit of the people and prevent injustice or kemādarātan

While jañmah hudūd is a crime committed by a person or more who make the perpetrator a convict with the threat of sanctions had. ${ }^{22}$ jañmah hudū $d$ is a criminal act with the form and limit of punishment in the Qur'an and the Sunnah of the Prophet Muhammad. At the same time, Jañmah ta'zīr is a criminal act whose form and threat of punishment are determined by the ruler (judge) as a lesson to the perpetrator ${ }^{23}$. The hudū $d$ and ta'zìr sanctions will be imposed after the sentencing process, which in Arabic terms is called 'uqübah, which is a form of retaliation for someone for his actions that violate the legal provisions set by Allah and His Messenger as the primary goal of achieving human benefit ${ }^{24}$. The purpose of punishment is the realization of the purpose of Islamic law itself, namely as retaliation for evil deeds, general prevention, and specific prevention and protection of the victim's rights. Sentencing with specific penalties is intended to benefit the people and prevent injustice or harm ${ }^{25}$.

The purpose of the punishment is viewed from the current positive law, which stems from the Western criminal law system that bases and justifies its theory of punishment on the view of social utility in the Qur'an and hadis. Islamic criminal law a practical level, both the Qur'an and the Sunnah of the Prophet contain only a tiny part of the theory on this matter. The rules given by the two sources are more general and are very likely to be interpreted in various ways. Although there is no denying the fact that the two sources of Islamic law specifically regulate several rules regarding the punishment of a particular crime, these rules are not numerous and generally relate to various topics of prohibition, or are permitted solely for the benefit of humans so that they are far from being damaged.

\footnotetext{
${ }^{21}$ Syafiq, "Rekonstruksi Pemidanaan Dalam Hukum Pidana Islam (Perspektif Filsafat Hukum)."

${ }^{22}$ Surya, "Klasifikasi Tindak Pidana Hudud Dan Sanksinya Dalam Perspektif Hukum Islam," 532.

${ }^{23}$ Zainuddin, Hukum Pidana Islam, 12.

${ }^{24}$ A. Rahman Ritonga, Ensiklopedi Hukum Islam (Jakarta: Ichtiar Baru Van Hoeve, 1997), 57.

${ }^{25}$ Moh. Ahsanuddin Jauhari, Filsafat Hukum Islam (Bandung: PT. Liventurindo, 2020), 177.
} 
In criminal acts, two things cannot be separated and are a link that will never be broken, namely criminal acts and punishment. A form of command and prohibition alone is not enough to encourage someone to leave an act or carry it out. For this reason, sanctions in the form of punishment are needed for anyone who violates it.

Punishment in the study of fiqh jināyah is grouped into several types, namely:

1. Punishment is seen in terms of the presence or absence of texts in the Qur'an and hadis. This case divided into two kinds:

a) The punishment contained in the texts of the Qur'an and hadis is hudūd, qișass, diyāt, and expiation. The example, in this case, is the punishment for adulterers, thieves, robbers, and others categorized as jarīmah hudūd, qiṣās and diyāt.

b) Punishment that is not contained in the texts of the Qur'an or hadis. This punishment is called ta'zīr punishment, such experiments do criminal acts $h u d \bar{u} d$, and $q i s ̦ a \bar{s}$ and diyāt were not finished, and criminal acts ta'zīr itself. ${ }^{26}$

2. Sentencing is seen from the relationship between one punishment and another. In this case, there are four kinds: ${ }^{27}$

a) Capital punishment, ie, criminal prosecution applied definitively, meaning that judges only apply by what has been determined by the texts. In fiqh jinā yah, this punishment is referred to as criminal acts (jañmah) hudūd.

b) Substitute punishment is applied as a substitute because the main punishment cannot be applied with valid/actual reasons. For example, qiṣās is replaced with diyāt, and diyāt is replaced by forgiveness.

c) Additional punishment accompanies the main crime without a separate judge's decision. For example, for the perpetrator of qazaf (accusing of adultery) punishment is imposed in the form of loss of the right to witness himself and the loss of inheritance rights for the perpetrator of the murder.

d) Complementary punishment is additional to the main punishment through a separate judge's decision. Complementary punishments are in line with other penalties because both are consequences/consequences of the main punishment. The difference between additional and complementary punishment is that further punishment does not require a separate judge's decision, while complimentary punishment requires a particular judge's decision.

3. Sentencing is seen from the authority of the judge in deciding cases. In this case, there are two kinds: ${ }^{28}$

a) Limited punishment, namely the criminal provisions determined by the texts, or in other words, there is no upper or lower limit - for example, the sentence of 100 lashes for adulterers and 80 lashes for the accused of adultery.

\footnotetext{
${ }^{26}$ Marsaid, Al-Fiqh Al-Jinayah ( Hukum Pidana Islam ), 58-59.

${ }^{27}$ Nur, Pengantar Dan Asas-Asas Hukum Pidana Islam, 49.

${ }^{28}$ siti Jahroh, "Reaktualisasi Teori Hukuman Dalam Hukum Pidana Islam," Jurnal Hukum Islam 9, no. 2 (2011): 189-203.
} 
b) Sentencing has alternatives to choose from because it has the highest and lowest limits. The judge can decide a sentence that is considered to reflect justice for the defendant. The judge's freedom is only in punishments belonging to the ta'zir group. For example, the judge can choose the convict to be imprisoned or flogged (volume). Regarding prison, the judge can decide how long he is imprisoned. ${ }^{29}$

4. Sentencing is seen from the object of the punishment. In this case, there are four kinds:

a) Corporal punishment, namely punishment imposed on human limbs such as cutting hands and flogging.

b) Punishment imposed on the soul, such as the death penalty.

c) Penalties imposed for the loss of human liberty or liberty, such as exile or imprisonment.

d) Penalties for the perpetrator's property include confiscation (confiscation), diyat, and fines ${ }^{30}$.

\section{Types of Crimes in The Qur'an}

In Islam, there are three kinds of crimes. First, Hudūd is the most severe crime against the public interest in Islamic criminal law. Crimes in this category are defined as crimes that are punishable by had is punishments that are determined as the right of Allah. Second, Qișāṣ. Qișāṣ is at the center position between hudūd and ta'zīr in severity. The target is the human body's integrity, intentionally or unintentionally, and the Third, Ta'zir. This crime is the basis of legal determination is ijma' (consensus) relating to the right of Muslim countries to criminalize and punish all inappropriate acts, which cause damage or loss, physical, social, political, financial, or moral to individuals or society as a whole. ${ }^{31}$

During this time, the Islamic criminal law is only considered to reply (retributive justice) to those who do evil because people only remember the qișās. Punishment in Islamic criminal law aims to establish justice (shown in sentence). sas-diyat Second, to deter perpetrators or unique prevention (as seen in the hudud punishment). Third, to provide general prevention/general prevention (see hudud punishment, and Fourth, improve perpetrators (appear in ta'zīr punishment). Even though Islamic criminal law has advantages, Islamic law is easy, far from complex, and narrow. Easy to practice, far from being petty, all its statutes always go hand in hand with human nature, Islamic law is by the provisions of right reason and logic and human nature before a character is damaged by lust, the purpose of Islamic law is only to realize the benefit of society, both in the world and in the hereafter, rejecting harm and evil, as

\footnotetext{
${ }^{29}$ Muchamad Iksan, “Asas Legalitas Dalam Hukum Pidana : Studi Komparatif Asas Legalitas Hukum Pidana Indonesia Dan Hukum Pidana Islam (Jinayah)," Jurnal Serambi Hukum 11, no. 01 (2017): 1-26.

${ }^{30}$ Rahmat Hakim, Hukum Pidana Islam (Fiqih Jinayah) (Bandung: Pustaka Setia, 2000).

${ }^{31}$ Muslich, “Ayat-Ayat Pidana Dalam Al-Qur'an.”
} 
well as realizing absolute justice, Islamic laws are azimah and rukhsah, and allow us to eat what is good and preen as long as it is not excessive and does not boast. ${ }^{32}$

Several crimes can be punished according to the Qur'an and the Sunnah of the Prophet Muhammad saw. Among them. First, the punishment of the perpetrator of the act of Zina. The word zina means fahissyah, which is a heinous act. In terms of adultery is a sexual relationship between a man and a woman who are not bound to each other in a marital relationship. The fuqaha define adultery as having sexual intercourse in the sense of inserting the penis (male sex) into a woman's vagina, which is declared haram, not because of doubt and based on lust ${ }^{33}$. According to Ibn Rushd, adultery is every intercourse that occurs not because of a legal marriage, not because of doubt, and not because of ownership (slaves) ${ }^{34}$.

The act of adultery is confirmed in the Qur'an and Sunnah, which must be punished (punishment). The fuqaha classify adultery in several categories, namely; In terms of the perpetrators of adultery, it is divided into two, namely adultery muh sān, namely adultery in which the perpetrator is husband, wife, widower, or widow, meaning that the perpetrator of adultery is a person who is still in marital status or has been legally married. The second is called adultery gairu muhsānn, namely adultery in which the perpetrator is still a virgin or a girl, meaning that the perpetrator has never been legally married and is not currently in a marriage bond ${ }^{35}$. Punishment for adultery unmarried (gairu muhsāann) based on the Qur'an in Surah An-Nur [24] verse 2, namely:

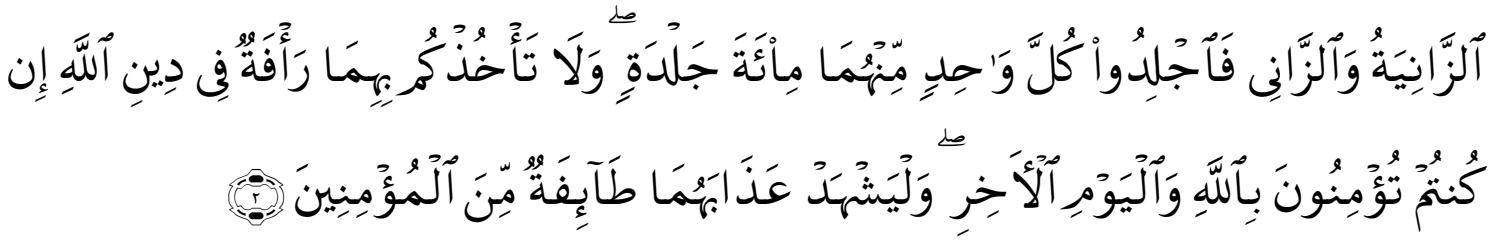

Translation: "The woman who commits adultery and the man who commits adultery, then lash each one of them a hundred lashes, and do not be merciful to them and prevent you from practicing Allah's religion, if you believe in Allah and the Last Day, and let ( execution of) their punishment was witnessed by a group of believers." (QS. An-Nur [24]: 2).

As for married people (muhsān) is stoning (stones) to death. The punishment is based on the Hadith of the Prophet, which means "take it from me! Take it from me! Take it from me! Allah has made way for them. Singles who commit adultery with bachelors are bound a hundred times and exiled for one year. Moreover, married people who commit adultery are lashed a hundred times and stoned with stones" (HR Muslim from 'Ubadah bin Shamit).

Second, the perpetrator's punishment of the act of Qaża f accusing (falsely Zina). Qażāf means throwing something. In terms of $q \dot{z} \dot{\bar{a}} f$ is an accusation against someone

\footnotetext{
${ }^{32}$ Suparman Usman and Itang, Filsafat Hukum Islam (Banten: Laksita Indonesia, 2015), 74.

${ }^{33}$ Surya, "Klasifikasi Tindak Pidana Hudud Dan Sanksinya Dalam Perspektif Hukum Islam."

${ }^{34}$ Ibnu Rusyd, Bidayatul Mujtahid Analisa Fiqh Para Mujtahid, Jilid 3 (Jakarta: Pustaka Amani, 2007), 600 .

${ }^{35}$ M. Nurul Irfan, Fiqh Jinayah (Jakarta: Amzah, 2015).
} 
that the accused has committed adultery ${ }^{36}$. In Islam, honor is a right that must be protected. Therefore, unproven accusations of adultery are considered very dangerous in society. So qaza $\bar{a} f$ is accusing someone muhsan (mature, sensible, independent, Muslim, and a good person) of committing adultery ${ }^{37}$. The punishment of the perpetrators of acts is qaża $f$ included in the category of hudud crimes threatened with severe punishment, which is 80 lashes. It is based on the Qur'an Surah An-Nur [24] verse 4, which reads:

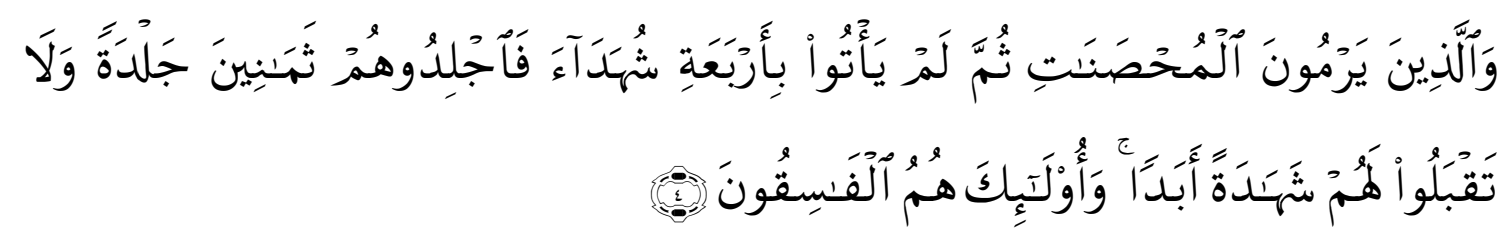

Translation: "And those who accuse good women (of adultery) and they do not bring four witnesses, then lash them (who accuses it) eighty lashes, and do not accept their testimony forever. And they are the wicked." (QS. An-Nur [24]:4).

The victims of this false accusation of adultery can be women and men. In verse, good women clearly stated examples because false accusations against women are more severe and eviler. There are three elements of this criminal act or qażāf; namely (1) accusing adultery or denying lineage; (2) the accused person is muhsan; and (3) there is bad faith ${ }^{38}$. The person who accuses adultery must prove the truth of his accusation. The accusation of adultery must be stated in explicit languages, such as "O adulterer" or "You have committed adultery" or "I have seen you commit adultery."

Meanwhile, against accusations in the form of satire, there must be other evidence that shows the intention of qadzaf. To accuse adultery is not required to use the words accusation, but enough to justify the accusation. For example, A says to B: "Your mother is an adulteress," then $\mathrm{C}$ says: "That's true," then $\mathrm{A}$ and $\mathrm{C}$ are both adulterers. However, the accusation requires that the target or the person accused be clear. In this crime, there is also required to be a lawsuit (complaint) from the person who is accused of adultery.

Evidence in this crime can be obtained either through the defendant's confession or the evidence of two witnesses. False charges of sodomy are also punishable by false accusations of adultery, but false accusations of lesbianism are not sentenced to hadd, but takzir at the judge's discretion.

Third, the punishment of the perpetrators of syarb al-Khāmr (drinking intoxicating drinks). Khāmr is an intoxicating drink. Then the word khāmr is the name of a drink that brings the drinker drunk or impaired consciousness. In classical times how to consume intoxicating objects was processed by humans in the form of

\footnotetext{
${ }^{36}$ Zainuddin, Hukum Pidana Islam.

${ }^{37}$ Irfan, Fiqh Jinayah.

${ }^{38}$ Santoso, Membumikan Hukum Pidana Islam.
} 
drinks so that the perpetrators were called drinkers. In the modern era, intoxicating objects can be packaged into various packages in the form of solid, liquid, and gas objects packaged into the form of food, beverages, tablets, capsules, or powders, according to the interests and conditions of the user. ${ }^{39}$ The criminal offense referred to in this discussion is all actions to consume food or drink through digestion or body tissues such as injecting and ways that make the wearer experience impaired consciousness $^{40}$. So syārb not only inserts intoxicating objects through the mouth and throat but also inserts objects into the body's organs from anywhere and in any way that can eliminate one's conscious thinking.

There are two elements in drinking $k h \bar{a} m r$, namely intoxicating drinks and bad intentions. What is meant by drinking is putting an intoxicating drink into the mouth and then swallowed into the stomach through the esophagus, even though it is mixed with other halal foods. ${ }^{41}$ As for what is meant by drunkenness according to Imam Abu Hanifah is the loss of mind, both a little or a lot so that it is not possible to distinguish between heaven and earth. Meanwhile, according to Abu Yusuf and Muhammad, what is meant by drunkenness is like the words of a delirious person, no longer coming out with awareness so that he does not know what he has said (Surah An-Nisa' verse 43). What is meant by having bad intentions is that you already know that intoxicating drinks are haram, but you still drink them ${ }^{42}$.

Prohibition of the intoxicating drink is based on the Qur'an Surah al-Maidah [5] verse 90, which reads:

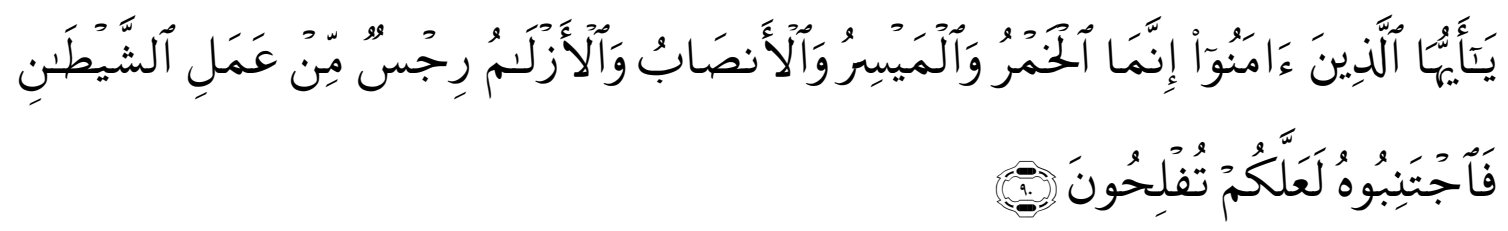

Translation: "O you who believe, indeed (drinking) khamr, (sacrificing for) idols, drawing fate with arrows are heinous acts, including the actions of the devil. So stay away from these actions so that you get good luck." (QS. Al-Maidah [5]: 4).

While the hadis of the Prophet explains: "Every intoxicant is khamr and every khamr is haram" (HR Abu Dawud from Ibn Umar), in another hadis, it is stated: "Something that if a lot intoxicates, then at least it is forbidden" (HR Ahmad). The Qur'an does not emphasize the punishment for the perpetrator. It was put down by the

\footnotetext{
${ }^{39}$ Ashar Ashar, "Konsep Khamar Dan Narkotika Dalam Al-Qur'an Dan UU," Fenomena 7, no. 2 (2015): 273-96, https://doi.org/10.21093/fj.v7i2.313.

${ }^{40}$ Zainuddin, Hukum Pidana Islam.

${ }^{41}$ Widya Pipit Herawati and Alfiah Rachmawati, "Hukuman Bagi Peminum Khamr Pada Putusan Pengadilan Negeri Klaten No 148/Pid.C/2018/ PN.Kln Dalam Tinjauan Fiqh Islam (Studi Perbandingan)," Sharia: Journal of Indonesian Comparative of LaW 3, no. 1 (2020): 73-90, https://doi.org/10.21111/jicl.v3i1.4514.

42 Erly Pangestu, "Minuman Keras Yang Berpengaruh Terhadap Timbulnya Kejahatan,” Jurnal Fakultas Hukum Universitas Tulungagung 1, no. 1 (2019): 21-30.
} 
Prophet, who through his Sunnah fi'liyāh it was known that the punishment for this finger was 40 lashes. Abu Bakr followed this trail. But Umar ibn Khattab dropped 80 lashes.

Fourth, the punishment of the perpetrators of the Maisir (Gambling) act. Gambling is an activity to take advantage of the form of games such as cards, cockfighting, playing ball, and other games, which do not imitate the perpetrators to be creative. The fuqaha do not place gambling and lotteries as one of the discussions in criminal offenses. When viewed from Islamic law, the prohibition on gambling is coupled with khämr. Based on this, it is quite reasonable if gambling is one of the criminal acts. The consequences or legal sanctions are aligned with crime khämr. Gambling can be categorized as a criminal act because it has a negative impact, including are 1) damaging the family economy, 2) disrupting community security, 3) crippling the creative spirit, 4) spending time, and so on ${ }^{43}$.

Fifth, criminal penalties against people who commit murder. Murder is an activity carried out by a person and/or several people which results in the death of a person and/or several persons. ${ }^{44}$ The act of killing can be classified in three forms, namely. First, intentional murder, namely the killing of someone against another person using a tool that is considered appropriate as a tool to kill. Second, unintentional murder is an act committed by someone with no intentional element that results in the death of another person. For example, someone cuts a tree, and then the tree that was cut fell on a passerby and died. Third, semi-intentional murder is an act that is intentionally committed by someone to another person with the aim of educating but resulting in the death of the student. For example, a teacher hits a ruler on the leg of a student, suddenly, the student who was beaten dies ${ }^{45}$.

Sixth, the punishment of people who commit violence so that the person is injured. An injury is an act committed by a person intentionally or unintentionally to injure or injure another person. Offense referred to in accordance with the word of God in the Qur'an Surah Al-Maidah [5] verse 45, which reads:

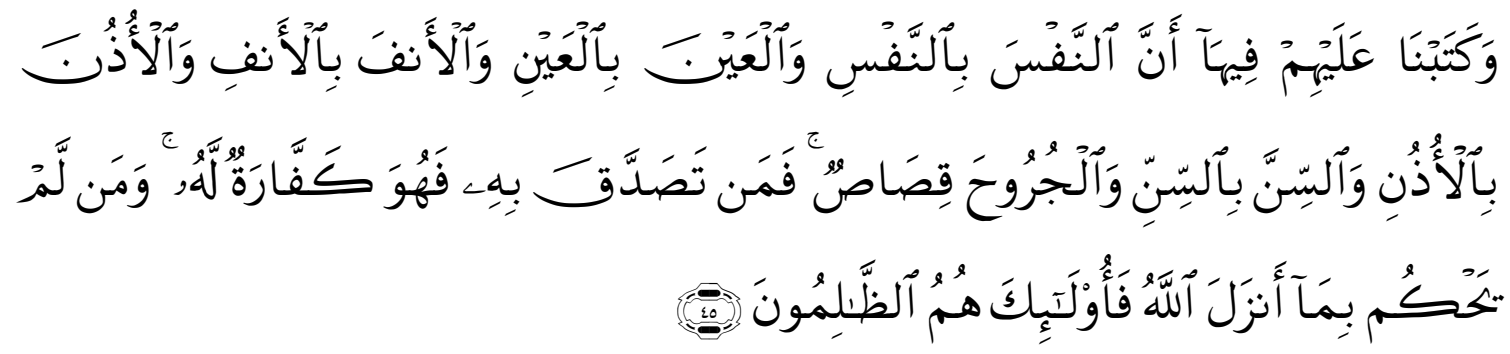

Translated: "And We have decreed for them in (at-Torah) that the soul is (repaid) for a soul, an eye for an eye, a nose for a nose, an ear for an ear, a tooth for a

\footnotetext{
${ }^{43}$ Zainuddin, Hukum Pidana Islam.

${ }^{44} \mathrm{R}$ Sinulingga and R Sugiharto, "Studi Komparasi Sanksi Pidana Pembunuhan Dalam Kitab Undang-Undang Hukum Pidana (KUHP) Dengan Hukum Islam Dalam Rangka Pembaharuan Hukum Pidana," Sultan Agung Fundamental Research Journal 1, no. 1 (2020): 31-43.

${ }^{45}$ Zainuddin, Hukum Pidana Islam.
} 
tooth, and wounds there lukapunqisas.his Anyone who releases (right qisas)it, then release the right (be) a sin for him. Whoever does not decide matters according to what Allah has revealed, then they are the wrongdoers." (QS. Al-Maidah [5]: 45).

Seventh, People who commit theft can be given criminal penalties because they can harm other people. A thief is a person who secretly takes objects and/or property belonging to others for possession. ${ }^{46}$ In this sense, there are several human behaviors that are similar but not the same as a thief. There is nothing wrong with this, namely (1) cheating, namely taking other people's rights slyly so that other people suffer losses; (2) corruption, namely taking the rights of other people, either individuals or the community, by using their authority over their positions and/or powers, thereby harming other people; (3) bribing, namely giving something either in the form of goods and/or money or otherwise to another person so that the giver gains material or moral benefit; while the gift is another party who is harmed ${ }^{47}$.

According to Djazuli, there are four elements of theft, namely; (a) taking property secretly, i.e., taking property without the owner's knowledge and without his consent, such as taking things from someone else's house while the occupants are sleeping. Retrieval of property is considered perfect when the thief has removed the treasure from its place. The stolen item has changed hands from its owner. The stolen item has changed hands to the thief. (b) the stolen property is in the form of movable, valuable property, has a proper storage area, and reaches the nisab (3 dirhams/1/4 dirhams, 1 dinar or 10 dirhams / 4 dinars / 40 dirhams.) (c) the stolen property belongs to another person (d) there is bad faith, namely the thief is proven to know that the law of stealing is unlawful and by his actions, he intends to have the stolen goods without the knowledge and willingness of the owner ${ }^{48}$.

Eighth, People who commit hirābah (robbery) can be subject to punishment for harming others. Hirabah (robbery) is the act of taking property overtly violent or coercive. ${ }^{49}$ Technical operations of the robbery there are several possibilities, namely: (1) a person went with the intention to take possession openly and held intimidation, but he did not take the treasure and do not kill. (2 ) A person departs with the intention of taking property openly and then taking the said property but not killing (3) someone departed with the intention of robbing, then killed but did not take the victim's property. (4) a person goes out to rob, then he takes the treasure and kills the owner. The four possibilities include robbery as long as the person concerned intends to take property openly ${ }^{50}$.

\footnotetext{
${ }^{46}$ Ishaq, "Sanksi Pidana Perampokan Dalam KUHP Dan Hukum Pidana Islam," Ahkam XV, no. 2 (2015): 145-52.

${ }^{47}$ Zainuddin, Hukum Pidana Islam.

${ }^{48}$ A. Djazuli, Fiqh Jinayah (Upaya Menanggulangi Kejahatan Dalam Islam) (Jakarta: Raja Grafindo Persada, 1997).

${ }^{49}$ Ishaq, "Sanksi Pidana Perampokan Dalam KUHP Dan Hukum Pidana Islam."

${ }^{50}$ Djazuli, Fiqh Jinayah (Upaya Menanggulangi Kejahatan Dalam Islam).
} 
The legal basis hirābah actions mentioned in the Qur'an Surah Al-Maidah [5] verse 33, which reads:

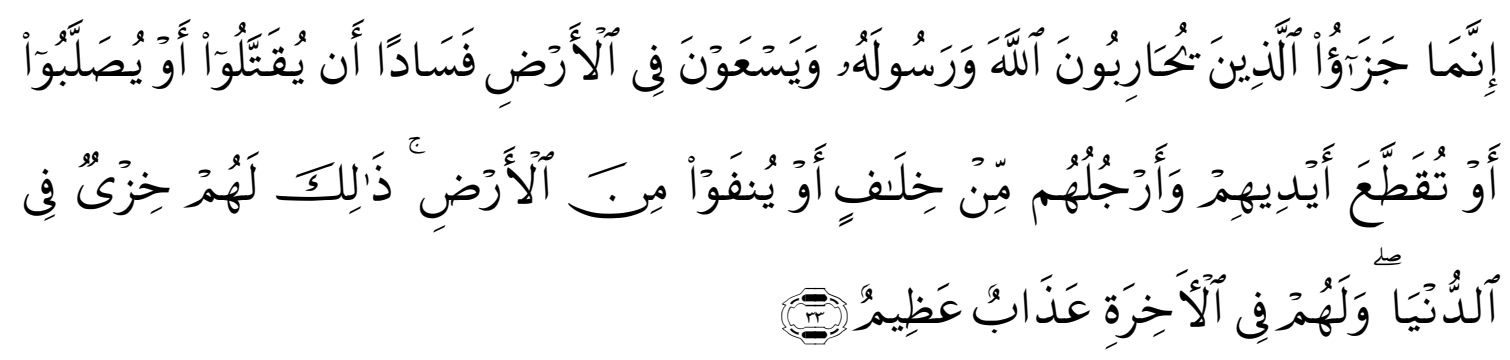

Translation: "Indeed, the recompense for those who fight against Allah and His Messenger causes mischief in the earth, is that they are killed or crucified or have their hands and feet cut off on opposite sides or are banished from the land (of their residence). That is an insult to them in this world and in the Hereafter they will have a great torment." (QS. AlMaidah [5]: 33).

On this basis, the scholars require that a robber must have the physical strength to coerce, even Imam Abu Hanifa and Imam Ahmad require that a robber must carry a sharp weapon, while according to Imam Shafi'i, it is important that a robber must have the physical strength to coerce ${ }^{51}$. Proof of robbery is by confession or two male witnesses. Sanctions for robbers according to Imam Abu Hanifah, Imam Syafii, and Imam Ahmad vary according to their actions. If he only intimidates, without taking property by force, but not while killing, then the penalty is cutting off his hands and feet crosswise. ${ }^{52}$ If you only kill without taking property, then the penalty is the death penalty. According to Imam Malik, the hirābah sanction is left to the imam to choose one of the punishments listed in verse above in accordance with the benefit ${ }^{53}$.

Ninth, people who commit acts of al-bāgyu (rebellion) can be subject to punishment for endangering the state. According to the language of al-bāgyu it means choosing something, while according to 'uruf, it is asking for something that is not lawful or violates rights. This is in accordance with the word of God in QS al-'Araf [7 ] verse 33, which reads:

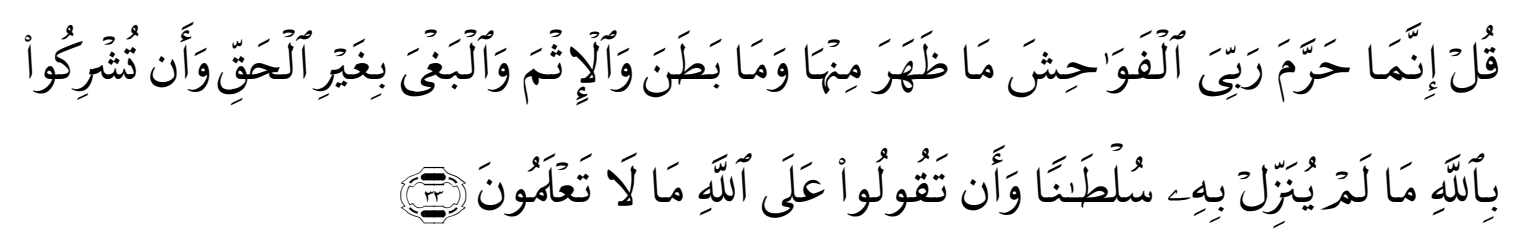

Translation: "My Lord only forbids abominable acts, both visible and hidden and sinful acts, violating human rights without a just reason" (QS.Al-A'raf [7]: 33).

\footnotetext{
${ }^{51}$ Djazuli.

${ }^{52}$ Ishaq, "Sanksi Pidana Perampokan Dalam KUHP Dan Hukum Pidana Islam."

${ }^{53}$ Djazuli, Fiqh Jinayah (Upaya Menanggulangi Kejahatan Dalam Islam).
} 
In defining $a l-b \bar{a} g y u$, scholars disagree. Hanafi scholars interpret it as a person's exit from obedience to a legitimate imam without reason. Shafi'i scholars define it as Muslims who violate the Imam by disobeying him and breaking away from him or rejecting obligations by having power, having arguments, and having leaders ${ }^{54}$.

There are two main elements in rebellious actions, namely; first, leaving the Imam openly that is opposing and trying to overthrow the Imam or rejecting everything that is required by him. The scholars agreed that it could even be obligatory to disobey the Imam if he ordered things that were immoral. Second, there are bad intentions or bad intentions from the rebels, namely, they intend to use force to overthrow the Imam or to disobey him ${ }^{55}$. Among the four schools of thought, even though justice is a requirement for a leader, it is forbidden to leave a wicked priest, even if it is for amār ma'nuff nah 'an al-munkār (invites to good and forbids to evil), because leaving the power of the priest is usually more evil, namely bringing slander, bloodshed, shaking the government, the spread of mafsadat and disruption of the order of life. It was also agreed by the ulema that the attack on the rebels should be preceded by contacting and asking them the reasons that led them out of obedience to the Imam, and the Imam should first invite them to obedience. This is in accordance with the word of Allah in Surah al-Hujarat [49] verse 9, which reads:

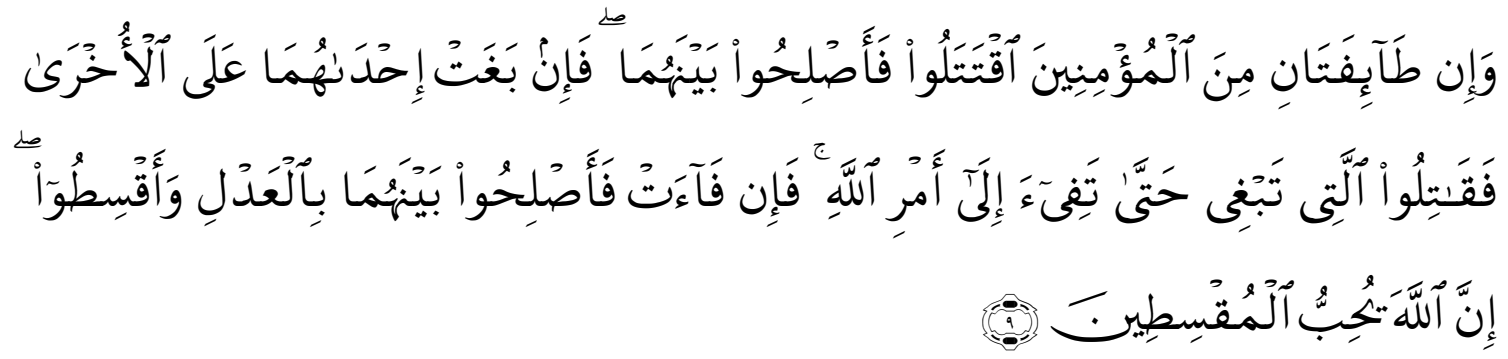

Translation: "And if there are two groups of believers fighting, then make peace between them. If one of the two groups persecutes another group, then fight the group that persecutes it back to Allah's command." (Surat alHujarat [49]: 9).

Tenth, a person who commits an act of criminal acts riddāh (apostasy) can be given a criminal penalty for destroying that person's faith. Riddāh literally means back, according to the Personality riddāh is out of Islam. According to Imam AnNawawi ridda $h$ is disconnected coupled with Islam with the intention of (speech) and the action of kufr, both intended to offend, oppose, or believe (this kufr). As for actions that result in the perpetrator being considered an infidel, the intention is to openly insult the religion or expressly reject the religion, such as throwing the manuscripts of the Qur'an into a dirty place and prostrating to idols or the sun ${ }^{56}$. In a hadis, the Messenger of Allah said: "Whoever changes his religion, kill him" (Narrated by

\footnotetext{
${ }^{54}$ Marsaid, Al-Fiqh Al-Jinayah ( Hukum Pidana Islam ), 66.

${ }^{55}$ Djazuli, Fiqh Jinayah (Upaya Menanggulangi Kejahatan Dalam Islam).

${ }^{56}$ Irfan, Fiqh Jinayah.
} 
Bukhāri from ibn Abbās). These traditions strengthen Allah says in Surah Al-Baqarah [2] verse 217 reads:

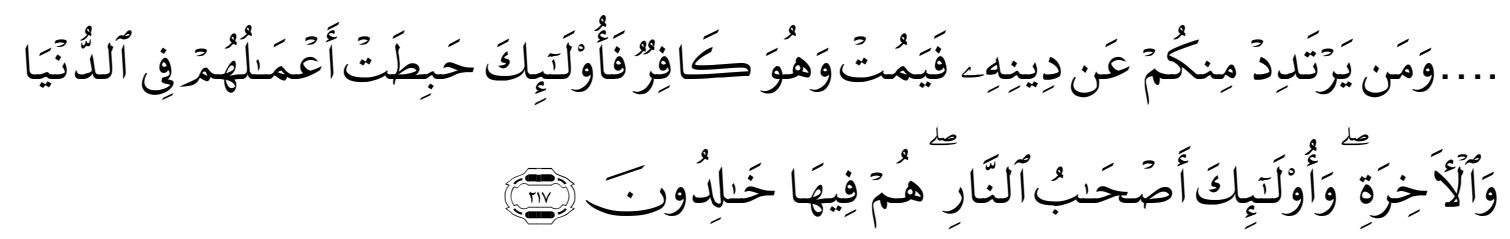

Translation: "..Whoever among you apostates from his religion, and then he dies in disbelief, then they are the ones whose deeds are in vain in this world and in the hereafter and they are the inhabitants of Hell, they will abide in it" (QS. Al-Baqarah). [2]: 217).

The element of riddāh is leaving Islam and having bad intentions. What is meant by leaving Islam can occur in three categories, namely apostasy by actions or leaving deeds, apostasy with words, and apostasy with intentions. Haram by considering it not haram or leaving an obligatory act by considering it as an act that is not obligatory, either intentionally or by ignoring it. For example, prostrating to the sun or the moon, throwing the Qur'an, and adultery by assuming adultery is not a haram act. What is meant by apostasy by speech is speech that points to disbelief, such as stating that Allah has children with the assumption that such speech is not prohibited. As for what is meant by apostasy by faith, it is an intention that is not in accordance with the Islamic creed, such as the eternal nature of nature, Allah is the same as a creature ${ }^{57}$. This act of ridda $h$ is unlawful closely related to intention and intentionality.

\section{Conclusion}

Punishment in the Qur'an is oriented towards human problems in this world and in the hereafter. That is, punishment will be directed at the perpetrator of an act that has been forbidden by Allah, whose prohibition carries a punishment that is determined by Him. Legal prohibition means doing a prohibited act or not doing an act that is not ordered. Thus, a crime is an act that is only prohibited by the Shari'a. There are ten acts that can be criminalized with threats of hạad and qișāṣ sanctions, namely adultery, qażāf (accusing adultery without evidence), hirābah (robbery), sarīqah (theft), syurb alkhāmr (drinking wine), mais̄̄r (gambling), riddāh (apostasy), murder, persecution, and al-būgyu(rebellion).

\footnotetext{
${ }^{57}$ A. Djazuli, Fiqh Jinayah, 114
} 


\section{REFERENCES}

Alotaibi, Hajed A. "The Challenges of Execution of Islamic Criminal Law in Developing Muslim Countries: An Analysis Based on Islamic Principles and Existing Legal System.” Cogent Social Sciences 7, no. 1 (2021): 1-13. https:// doi.org/10.1080/23311886.2021.1925413.

Ashar, Ashar. "Konsep Khamar Dan Narkotika Dalam Al-Qur'an Dan UU." Fenomena 7, no. 2 (2015): 273-96. https://doi.org/10.21093/fj.v7i2.313.

Chazawi, Adami. Pelajaran Hukum Pidana Bagian I. Jakarta: Raja Grafindo Persada, 2012.

Djazuli, A. Fiqh Jinayah (Upaya Menanggulangi Kejahatan Dalam Islam). Jakarta: Raja Grafindo Persada, 1997.

Fallon, Andrew. "Restoration as the Spirit of Islamic Justice." Contemporary Justice Review: Issues in Criminal, Social, and Restorative Justice 23, no. 4 (2019): 1-14. https://doi.org/10.1080/10282580.2019.1700370.

Hakim, Rahmat. Hukum Pidana Islam (Fiqih Jinayah). Bandung: Pustaka Setia, 2000.

Herawati, Widya Pipit, and Alfiah Rachmawati. "Hukuman Bagi Peminum Khamr Pada Putusan Pengadilan Negeri Klaten No 148/Pid.C/2018/ PN.Kln Dalam Tinjauan Fiqh Islam (Studi Perbandingan)." Sharia: Journal of Indonesian Comparative of Law 3, no. 1 (2020): 73-90. https://doi.org/10.21111/ jicl.v3i1.4514.

Husnawadi. "Konsep Hukum Pidana Dalam Al-Qur'an." Al Aqidah: Jurnal Studi Islam 1, no. 1 (2018): 1-19.

Iksan, Muchamad. "Asas Legalitas Dalam Hukum Pidana: Studi Komparatif Asas Legalitas Hukum Pidana Indonesia Dan Hukum Pidana Islam (Jinayah).” Jurnal Serambi Hukum 11, no. 01 (2017): 1-26.

Irfan, M. Nurul. Fiqh Jinayah. Jakarta: Amzah, 2015.

Ishaq. "Sanksi Pidana Perampokan Dalam KUHP Dan Hukum Pidana Islam." Ahkam XV, no. 2 (2015): 145-52.

Jahroh, Siti. "Reaktualisasi Teori Hukuman Dalam Hukum Pidana Islam." Jurnal Hukum Islam 9, no. 2 (2011): 189-203.

Jauhari, Moh. Ahsanuddin. Filsafat Hukum Islam. Bandung: PT. Liventurindo, 2020.

Maramis, Frans. Hukum Pidana Umum Dan Tertulis Di Indonesia. Jakarta: Raja Grafindo Persada, 2016.

Marsaid. Al-Fiqh Al-Jinayah ( Hukum Pidana Islam ). Palembang: Rafah Press, 2020.

Moeljatno. Asas-Asas Hukum Pidana. Jakarta: Reneka Cipta, 1993.

Muslich, Ahmad Wardi. Pengantar Dan Asas Hukum Pidana Islam (Fikih Jinayah). Jakarta: Sinar Grafika, 2006.

Muslich, H.A. Wardi. “Ayat-Ayat Pidana Dalam Al-Qur'an.” Al-Qalam: Jurnal Kajian Keislaman 18, no. 90-91 (2001): 46-73.

Nur, Muhammad. Pengantar Dan Asas-Asas Hukum Pidana Islam. Banda Aceh: Yayasan PeNA Aceh, 2020.

Pangestu, Erly. "Minuman Keras Yang Berpengaruh Terhadap Timbulnya Kejahatan." Jurnal Fakultas Hukum Universitas Tulungagung 1, no. 1 (2019): 21-30.

Ritonga, A. Rahman. Ensiklopedi Hukum Islam. Jakarta: Ichtiar Baru Van Hoeve, 1997. 
Rusyd, Ibnu. Bidayatul Mujtahid Analisa Fiqh Para Mujtahid, Jilid 3. Jakarta: Pustaka Amani, 2007.

Sahid. Epistemologi Hukum Pidana Islam (Dasar-Dasar Pidana Islam). Surabaya: Pustaka Idea, 2015.

Santoso, Topo. Membumikan Hukum Pidana Islam. Jakarta: Gema Insani Press, 2003.

Sinulingga, R, and R Sugiharto. "Studi Komparasi Sanksi Pidana Pembunuhan Dalam Kitab Undang-Undang Hukum Pidana (KUHP) Dengan Hukum Islam Dalam Rangka Pembaharuan Hukum Pidana." Sultan Agung Fundamental Research Journal 1, no. 1 (2020): 31-43.

Sunarto. "Konsep Hukum Pidana Islam Dan Sanksinya Dalam Perspektif Al-Qur'an." Kordinat: Jurnal Komunikasi Antar Perguruan Tinggi Agama Islam XIX, no. 1 (2020): 97-112.

Surya, Reni. "Klasifikasi Tindak Pidana Hudud Dan Sanksinya Dalam Perspektif Hukum Islam.” Samarah: Jurnal Hukum Keluarga Dan Hukum Islam 2, no. 2 (2018): 530-47.

Syafiq, Ahmad. "Rekonstruksi Pemidanaan Dalam Hukum Pidana Islam (Perspektif Filsafat Hukum)." Jurnal Pembaharuan Islam 1, no. 2 (2014): 178-90.

Usman, Suparman, and Itang. Filsafat Hukum Islam. Banten: Laksita Indonesia, 2015.

Zainuddin. Pengantar Hukum Pidana Islam. Yogyakarta: Deepublish, 2019.

Zainuddin, Ali. Hukum Pidana Islam. Jakarta: Sinar Grafika, 2007. 